\title{
Wisata Puncak Becici: Kepuasan, Loyalitas, Dan Intensi Rekomendasi Wisatawan
}

Isnanda Zainur Rohman

isnanda.zainur@stieykpn.ac.id

Program Studi S1 Manajemen, STIE YKPN Yogyakarta, Jl Seturan Raya 55281, Sleman, Daerah Istimewa Yogyakarta.

\begin{abstract}
This study aims to determine the effect of tourist satisfaction on tourist loyalty. Then, the impact of tourist loyalty on the intention of tourists to recommend others visit the tourist attractions. A total of 221 respondents filled out the questionnaire given by the researcher when they visited a tourist attraction, Puncak Becici Yogyakarta. This place is a new destination in Yogyakarta, so research is needed to make this place better. The hypotheses were tested by regression analyses. The results showed that tourist satisfaction has a positive effect on tourist loyalty. Then, tourist loyalty has a positive effect on the intention of tourist recommendations. The implication is that people managing tourist attractions need to maintain the level of tourist satisfaction so that tourists become loyal, and then they will have the intention to recommend others visit.
\end{abstract}

Keyword: Puncak Becici, tourist satisfaction, tourist loyalty, and intention to recommend

\section{PENDAHULUAN}

Pariwisata merupakan salah satu sektor unggulan pemerintah Indonesia untuk meningkatkan kondisi perkonomian (Kemenpar, 2016). Dengan keindahan alam yang dimiliki negara Indonesia, terdapat banyak tempat yang dapat dijadikan destinasi wisata baru. Selaras dengan kebijakan pemerintah di dalam rencana strategis kementerian pariwisata 2015-2019, pemerintah mendukung tumbuhnya objek wisata baru. Dalam satu dekade terakhir, terdapat banyak daya tarik wisata atau objek wisata yang dikembangkan oleh pemerintah, salah satunya adalah objek wisata Puncak Becici.

Objek wisata Puncak Becici berada di Desa Muncuk, Dlingo, Bantul, Daerah Istimewa Yogyakarta. Berada di objek wisata ini, wisatawan dapat menikmati panorama keindahan alam dari atas bukit. Objek wisata ini semakin menarik perhatian masyarakat luas saat mantan presiden Amerika Serikat, Barack Obama, mengunjunginya pada pertengahan tahun 2017. Selain mengunjungi objek wisata yang sudah mendunia seperti Candi Borobudur, mantan presiden Amerika Serikat tersebut di luar dugaan memilih Puncak Becici sebagai salah satu tempat wisata yang dikunjungi.

Terdapat banyak tempat menarik yang dapat digunakan untuk berfoto di Puncak Becici. Wisata alam ini dapat menjadi tempat favorit baru di antara tempat wisata lain di Daerah Istimewa Yogyakarta. Sebagai objek wisata baru, Puncak Becici perlu mendapatkan banyak kajian. Untuk mendukung strategi pemasarannya, penelitian ini akan membahas lebih dalam tentang tingkat kepuasan, loyalitas, dan intensi rekomendasi wisatawan.

Meskipun pemerintah sudah banyak mengembangkan objek wisata baru, namun tidak semuanya berjalan dengan sukses (Lestari, 2016). Tidak sedikit objek wisata yang harus tutup karena wisatawan merasa tidak puas. Untuk bisa menjaga keberlangsungan objek wisata Puncak Becici, maka perlu adanya penelitian dalam membantu pengelola dalam pengambilan keputusan. Penelitian manajemen pemasaran pariwisata yang dilaksanakan di objek Puncak Becici belum banyak dilakukan sehingga penelitian dilakukan dan berwujud dalam artikel ilmiah ini.

Fokusnya adalah kepuasan, loyalitas, dan intensi rekomendasi wisatawan. Adanya tingkat intensi rekomendasi yang tinggi dari wisatawan, jumlah pengunjung akan meningkat (Altunel \& Erkut, 2015). Salah satu faktor wisatawan memiliki intensi untuk merekomendasikan adalah loyalitas. Loyalitas wisatawan merupakan indikator bahwa sebuah objek wisata mampu memikat hati wisatawan untuk berkunjung kembali (Wu, 2016). Kepuasan wisatawan adalah salah satu hal penting bagi pemasar pariwisata. Jika pengelola mengetahui seberapa tinggi tingkat kepuasan wisatawan, maka pengelola dapat melihat sejauh mana kesuksesannya dalam mengelola objek wisata (Hultman, Skarmeas, Oghazi, \& Beheshti, 2015). Ketiga variabel di atas akan dibahas dan dikaji lebih lanjut di dalam penelitian ini. 


\section{KEPUSTAKAAN}

Wisatawan adalah aset berharga bagi sebuah objek wisata (Franklin, 2015). Jika sebuah objek wisata dikunjungi oleh banyak wisatawan, maka objek wisata tersebut bisa dikatakan berhasil (Garg, 2016). Adanya wisatawan yang berkunjung, maka pengelola akan mendapatkan pemasukan dari tiket dan retribusi parkir kendaraan pengunjung. Lebih dari itu, banyak pelaku usaha yang akan diuntungkan jika terdapat banyak wisatawan yang berkunjung. Pelaku usaha yang dimaksud adalah pengusaha agen travel, penjual makanan dan minuman, perajin suvenir, penjual souvenir, pemandu wisata, dan lain-lain.

Banyaknya wisatawan yang berkunjung merupakan keuntungan bagi kondisi perekonomian sekitar terutama bagi pelaku usaha di bidang pariwisata. Hal ini mendorong, seluruh pelaku usaha perlu mengupayakan peningkatan jumlah wisatawan yang berkunjung. Salah satu hal yang mempengaruhi peningkatan jumlah wisatawan adalah rekomendasi dari wisatawan yang pernah berkunjung (Antón, Camarero, \& Laguna-García, 2017).

Rekomendasi dari wisatawan yang berkunjung dianggap terpercaya karena mereka sudah merasakan dan menikmati objek wisata tersebut (Majid, Chen, Mirza, Hussain, \& Chen, 2015). Rekomendasi ini lebih dipercaya dibandingkan dengan promosi yang dilakukan oleh pengelola objek wisata. Jika pengelola objek wisata berpromosi dengan cara berbayar, maka rekomendasi wisatawan sifatnya gratis karena dilakukan dengan sukarela. Rekomendasi dari wisatawan dapat berupa rekomendasi langsung maupun rekomendasi melalui media sosial. Dalam penelitian ini, rekomendasi wisatawan mencakup keduanya. Hampir setiap wisatawan mengunggah foto mereka saat berkunjung ke suatu tempat (Bigne, Andreu, Hernandez, \& Ruiz, 2018). Seperti membagikan kenangan di media sosial, teman dan pengikut mereka akan tertarik untuk berkunjung ke objek wisata tersebut.

Intensi adalah keinginan dari seseorang untuk melakukan sesuatu (Sheeran \& Webb, 2016). Intensi merupakan kemauan dan dorongan pada hal yang ingin dilakukan (Stylos, Vassiliadis, Bellou, \& Andronikidis, 2016). Intensi rekomendasi adalah kemauan seseorang untuk memberikan rekomendasi kepada orang lain (Astiarini, 2018). Jadi, intensi rekomendasi wisatawan yang dimaksud disini adalah keinginan dari dalam hati wisatawan untuk merekomendasikan objek wisata yang dikunjungi.

Faktor lain yang perlu dikaji dalam pengembangan objek wisata baru adalah loyalitas wisatawan (Utami \& Ferdinand, 2019). Jika wisatawan memiliki tingkat loyalitas yang tinggi, maka bisa dikatakan objek wisata tersebut berhasil (Wu, 2016). Loyalitas wisatawan adalah kesetiaan dari pengunjung untuk tetap berkunjung ke suatu objek wisata pada suatu saat. Loyalitas wisatawan merupakan bagian penting saat mempelajari pemasaran pariwisata. Loyalitas wisatawan didefinisikan sebagai tingkat kesetiaan pengunjung pada objek wisata (Zhang, Fu, Cai, \& Lu, 2014).

Kepuasan wisatawan merupakan salah satu hal yang berdampak pada tingkat loyalitas wisatawan. Kepuasan wisatawan adalah sesuatu yang dirasakan oleh wisatawan saat dan setelah berkunjung ke suatu objek wisata (Alegre \& Garau, 2010). Kepuasan wisatawan merupakan hasil perbandingan ekspektasi wisatawan sebelum berkunjung dengan kenyataan yang ia dapatkan saat berkunjung ke suatu objek wisata (Hermawan, 2017).

Tingkat kepuasan wisatawan menunjukkan keberhasilan pengelola objek wisata (Kristanti \& Farida, 2016). Jika tingkat kepuasan tinggi, maka pengelola objek wisata berhasil dalam mengelola objek wisata. Dalam jangka panjang, kepuasan wisatawan mempengaruhi loyalitas wisatawan (Rajesh, 2017). Dari uraian di atas, maka hipotesis pertama dirumuskan sebagai berikut:

Hipotesis 1: Kepuasan berpengaruh positif terhadap loyalitas

Dalam beberapa penelitian sebelumnya, loyalitas wisatawan terbukti berpengaruh positif terhadap intensi rekomendasi wisatawan. Salah satu faktor yang mempengaruhi intensi rekomendasi adalah tingkat loyalitas wisatawan. Wisatawan yang loyal terhadap sebuah objek wisata akan dengan sukarela merekomendasikan objek wisata tersebut kepada orang lain. Dengan demikian, hipotesi ke2 dirumuskan seebagai berikut: 
Hipotesis 2: Loyalitas berpengaruh positif terhadap intensi rekomendasi wisatawan

\section{METODE PENELITIAN}

Lokasi penelitian di objek wisata Puncak Becici yang terletak di daerah Dlingo, Bantul, Daerah Istimewa Yogyakarta. Penelitian dilaksanakan selama 2 bulan yaitu pada bulan Agustus dan September 2019. Penelitian ini menggunakan data primer yang didapatkan langsung dari hasil penyebaran kuesioner. Data kuesioner didapatkan dari pengunjung objek wisata Puncak Becici. Pengunjung objek wisata ini diminta untuk mengisi kuesioner tertulis yang diberikan oleh peneliti. Pengambilan sampel dilakukan dengan metode purposive sampling.

Jenis penelitian ini adalah penelitian kuantitatif. Dalam penelitian kuantitatif, terdapat data yang diolah untuk menghasilkan suatu kesimpulan (Ghozali, 2016). Terdapat 3 variabel dalam penelitian ini yang diukur menggunakan kuesioner. Ketiga variabel diukur dengan skala Likert 5 poin. Penggunaan skala Likert 5 poin digunakan untuk mengetahui tingkat persetujuan responden terhadap pernyataan di dalam kuesioner. Skala 1 menunjukkan responden sangat tidak setuju, sedangkan skala tertinggi yaitu skala 5 menunjukkan responden sangat setuju. Terdapat 16 indikator yang mewakili 3 variabel: kepuasan, loyalitas, dan intensi rekomendasi wisatawan.

Tinggi atau rendahnya validitas pernyataan dalam kuesioner menunjukkan sejauh mana data yang terkumpul tidak meyimpang dari gambaran tentang variabel yang dimaksud. Sebuah pernyataan dalam kuesioner dikatakan valid jika mampu mengukur apa yang seharusnya diukur ditunjukkan dengan nilai loading factor $\geq 0,5$ (Sekaran \& Bougie, 2014)

Uji reliabilitas bertujuan untuk mengetahui sejauh mana kosistensi alat ukur yang digunakan, sehingga bila alat ukur tesebut digunakan kembali untuk meneliti objek yang sama dan dengan teknik yang sama pula walaupun waktunya berbeda, maka hasilnya akan sama. Uji reabilitas mampu menunjukan sejauh mana instrumen dapat dipercaya. Suatu instrumen dikatakan reliabel apabila nilai cronbach alpha $\geq 0,6$ (Sekaran \& Bougie, 2014).
Untuk menguji hipotesis, data dalam penelitian ini dianalisis menggunakan regresi linier, untuk mengetahui pengaruh dari variabel independen terhadap variabel dependen. Dalam analisis, peneliti menggunakan program komputer Statistical Package of Social Science (SPSS) version 23.0 for Windows.

\section{HASIL DAN PEMBAHASAN}

Data hasil kuesioner menunjukkan karakteristik responden dari berbagai latar belakang. Pekerjaan responden bervariasi yaitu pengusaha, pegawai negeri sipil, pegawai swasta, guru, pelajar, dan lain-lain. Responden didominasi oleh orang yang berusia 21-30 tahun dan pekerjaan mayoritas adalah pelajar. Mayoritas responden berpendidikan SMA dan jumlah responden wanita lebih banyak dari pria. Data karakteristik responden terdapat pada tabel 4.1 berikut:

Tabel 1.1 Karakteristik Responden

\begin{tabular}{|l|l|c|l|}
\hline \multicolumn{2}{|c|}{ Karakteristik } & Jumlah & Persentase \\
\hline Usia & $21-30$ tahun & 88 & $39,80 \%$ \\
& $31-40$ tahun & 65 & $29,55 \%$ \\
& $41-50$ tahun & 45 & $20,45 \%$ \\
& $51-60$ tahun & 23 & $10,20 \%$ \\
\hline Pekerjaan & Pengusaha & 50 & $22,75 \%$ \\
& PNS & 23 & $10,25 \%$ \\
& Swasta & 40 & $18,25 \%$ \\
& Guru & 39 & $17,95 \%$ \\
& Pelajar & 49 & $22,05 \%$ \\
& Lain-lain & 19 & $8,75 \%$ \\
\hline Pendidikan & SMA & 144 & $65,33 \%$ \\
terakhir & S1 & 53 & $24,02 \%$ \\
& S2 & 24 & $10,65 \%$ \\
\hline Jender & Pria & 118 & $46,55 \%$ \\
& Wanita & $53,45 \%$ \\
\hline
\end{tabular}

Pengolahan data selanjutnya dilakukan dalam tiga tahap. Pertama, data kuesioner diuji validitasnya. Hasil olah data menunjukkan bahwa semua pernyataan dalam kuesioner valid. Hal ini dapat ditunjukkan dari nilai loading factor $\geq 0,5$ untuk semua item kuesioner. Kedua, uji reliabilitas dilakukan untuk menguji kehandalan alat ukur yang digunakan. Hasil uji reliabilitas pada 3 variabel menunjukkan cronbach's alpha lebih dari 0,6 sehingga dapat dikatakan reliabel. Ketiga, data diuji dengan teknik uji regresi linier. Hasil uji regresi hipotesis pertama menunjukkan bahwa variabel kepuasan wisatawan berpengaruh positif pada loyalitas wisatawan. Hasil uji regresi hipotesis kedua menunjukkan bahwa loyalitas wisatawan 
berpengaruh positif pada intensi rekomendasi. Dapat dilihat pada tabel 4.2, kedua uji hipotesis memiliki nilai sig. $=0,000$ dan koefisien $(\beta)$ positif yang artinya berpengaruh positif.

Tabel 4.2 Uji Regresi

\begin{tabular}{|l|c|c|c|}
\hline \multicolumn{1}{|c|}{ Hipotesis } & $\begin{array}{c}\text { Koefisien } \\
(\beta)\end{array}$ & Sig. & Keterangan \\
\hline $\begin{array}{l}\text { Kepuasan } \\
\text { berpengaruh } \\
\text { positif } \\
\text { terhadap } \\
\text { loyalitas }\end{array}$ & 0,311 & 0,000 & $\begin{array}{c}\text { Hipotesis } \\
\text { diterima }\end{array}$ \\
\hline $\begin{array}{l}\text { Loyalitas } \\
\text { berpengaruh } \\
\text { positif } \\
\text { terhadap } \\
\text { intensi } \\
\text { rekomendasi } \\
\text { wisatawan }\end{array}$ & 0,533 & 0,000 & $\begin{array}{c}\text { Hipotesis } \\
\text { diterima }\end{array}$ \\
\hline
\end{tabular}

Berdasarkan hasil uji di atas, terbukti bahwa kepuasan wisatawan berpengaruh positif terhadap loyalitas wisatawan. Hal ini dapat dilihat dari nilai signifikansi pengaruh kepuasan wisatawan terhadap loyalitas wisatawan kurang dari 0,05 dan nilai koefisien $(\beta)$ yang positif. Sesuai hasil penelitian sebelumnya, kepuasan wisatawan berpengaruh positif terhadap loyalitas wisatawan (Meesala \& Paul, 2018; Stathopoulou \& Balabanis, 2016). Jika wisatawan memiliki tingkat kepuasan yang tinggi maka tingkat loyalitas wisatawan akan tinggi.

Kepuasan merupakan rasa cukup yang muncul pada diri seseorang. Jika pengunjung objek wisata memiliki ekspektasi sebelum berkunjung, mereka akan membandingkan ekspektasi tersebut dengan kenyataannya. Saat pengunjung merasa puas dengan sebuah objek wisata, ia akan cenderung menjadi loyal terhadap sebuah objek wisata.

Kepuasan wisatawan adalah hal yang sangat penting bagi keberlangsungan sebuah objek wisata (Rajesh, 2017). Dengan adanya tingkat kepuasan yang tinggi dari wisatawan, sebuah objek wisata bisa dikatakan sukses. Jika wisatawan merasa puas, maka ia akan menjadi wisatawan yang loyal (Hultman et al., 2015). Artinya, suatu saat ia akan berkunjung kembali ke objek wisata tersebut.

Dari hasil olah data regresi kedua, dapat dilihat bahwa loyalitas wisatawan berpengaruh positif terhadap intensi rekomendasi wisatawan. Hal ini dapat ditunjukkan dari tingkat signifikansi pengaruh loyalitas wisatawan terhadap intensi rekomendasi kurang dari 0,05 dan koefisien $(\beta)$ yang positif. Hasil ini sesuai dengan penelitiaan sebelumnya bahwa loyalitas wisatawan berpengaruh positif terhadap intensi rekomendasi (Xu, Peak, \& Prybutok, 2015). Dengan tingginya tingkat loyalitas wisatawan, maka wisatawan tersebut akan memiliki tingkat intensi yang tinggi untuk merekomendasikan objek wisata ke orang lain.

Loyalitas wisatawan dapat menjadi tolok ukur keberhasilan sebuah tempat wisata $(\mathrm{Wu}$, 2016). Loyalitas wisatawan adalah keinginan untuk tetap mengunjungi sebuah objek wisata pada masa yang akan datang. Dengan demikian, wisatawan akan memiliki keinginan untuk merekomendasikan objek wisata tersebut ke orang lain. Seseorang menjadi loyal karena memiliki alasan, begitu pula dengan dengan orang lain. Alasan tersebut yang akan dibagikan kepada orang lain sehingga orang lain dapat tertarik juga untuk berkunjung.

Intensi rekomendasi wisatawan merupakan hal yang esensial bagi pemasar pariwisata. Jika wisatawan memiliki keinginan untuk memberikan rekomendasi tentang sebuah objek wisata, maka dapat dikatakan pemasar pariwisata tersebut berhasil untuk memasarkan sebuah objek wisata. Intensi rekomendasi memiliki efek yang cukup signifikan bagi pemasaran pariwisara. Dengan demikian, diharapkan jumlah wisatawan yang berkunjung akan meningkat.

\section{KESIMPULAN}

Hasil penelitian menunjukkan bahwa kepuasan wisatawan berpengaruh positif terhadap loyalitas wisatawan. Semakin tinggi tingkat kepuasan wisatawan, maka semakin tinggi tingkat loayalitasnya. Dengan demikian, pengelola objek wisata perlu memberikan perhatian khusus agar tingkat kepuasan wisatawan meningkat. Kesimpulan kedua adalah loyalitas wisatawan berpengaruh positif terhadap intensi rekomendasi wisatawan. Semakin tinggi tingkat loyalitas wisatawan, maka semakin tinggi intensi untuk merekomendasikan objek wisata tersebut ke orang lain untuk dikunjungi. Keterbatasan dalam penelitian ini adalah metode pengumpulan data yaitu menggunakan kuesioner tertulis. Saran untuk penelitian selanjutnya adalah perlu informasi yang lebih mendalam dengan 
melakukan wawancara kepada responden sehingga didapatkan hasil yang lebih spesifik.

\section{DAFTAR PUSTAKA}

Alegre, J., \& Garau, J. (2010). Tourist Satisfaction and Dissatisfaction. Annals of Tourism Research. Https://Doi.Org/10.1016/J.Annals.2009.07.001

Antón, C., Camarero, C., \& Laguna-García, M. (2017). Towards A New Approach of Destination Loyalty Drivers: Satisfaction, Visit Intensity and Tourist Motivations. Current Issues In Tourism. Https://Doi.Org/10.1080/13683500.2014.9368 34

Astiarini, D. (2018). Helpfulness of Online Review: A Role of Review Valence (Case Study of Amazon.Com). Jurnal Riset Ekonomi Manajemen (Rekomen). Https://Doi.Org/10.31002/Rn.V1i1.558

Bigne, E., Andreu, L., Hernandez, B., \& Ruiz, C. (2018). The Impact Of Social Media And Offline Influences On Consumer Behaviour. An Analysis Of The LowCost Airline Industry. Current Issues in Tourism. Https://Doi.Org/10.1080/13683500.2015.1126 236

Cevdet Altunel, M., \& Erkut, B. (2015). Cultural Tourism In Istanbul: The Mediation Effect of Tourist Experience and Satisfaction on The Relationship Between Involvement And Recommendation Intention. Journal of Destination Marketing And Management.

Https://Doi.Org/10.1016/J.Jdmm.2015.06.003

Franklin, A. (2015). Tourist Studies. In The Routledge Handbook of Mobilities. Https://Doi.Org/10.4324/9781315857572.Ch6

Garg, A. (2016). Travel Risks vs Tourist Decision Making: A Tourist Perspective. International Journal of Hospitality And Tourism Systems. Https://Doi.Org/10.21863/Ijhts/2015.8.1.004

Ghozali, I. (2016). Aplikasi Analisis Multivariete dengan Program IBM SPSS 23, Edisi 8. In Badan Penerbit Universitas Diponegoro.

Hermawan, H. (2017). Pengaruh Daya Tarik Wisata, Keselamatan dan Sarana Wisata terhadap Kepuasan serta Dampaknya Terhadap Loyalitas Wisatawan : Studi Community based Tourism di Gunung Api Purba Nglanggeran. Wahana Informasi Pariwisata : Media Wisata.

Hultman, M., Skarmeas, D., Oghazi, P., \& Beheshti, H. M. (2015). Achieving Tourist Loyalty through Destination Personality, Satisfaction, and Identification. Journal of Business Research. Https://Doi.Org/10.1016/J.Jbusres.2015.06.002

Kemenpar. (2016). Pembangunan Destinasi Pariwisata Prioritas 2016 - 2019. Rapat Koordinasi Nasional Kementerian Pariwisata "Akselerasi Pembangunan Kepariwisataan Dalam Rangka Pencapaian Target 12 Juta Wisman Dan 260 Juta Wisnus 2016," 76.

Kristanti, L. T., \& Farida, N. (2016). Pengaruh Citra Destinasi dan Fasilitas Wisata terhadap Niat Berperilaku Melalui Kepuasan Sebagai Variabel Intervening (Studi Pada Pengunjung Museum Kereta Api Ambarawa). Jurnal Ilmu Administrasi Bisnis.
Lestari, G.-. (2016). Partisipasi Pemuda dalam Mengembangkan Pariwisata Berbasis Masyarakat untuk Meningkatkan Ketahanan Sosial Budaya Wilayah (Studi Di Desa Wisata Pentingsari, Umbulharjo, Cangkringan, Sleman, D.I. Yogyakarta). Jurnal Ketahanan Nasional. Https://Doi.Org/10.22146/Jkn.17302

Majid, A., Chen, L., Mirza, H. T., Hussain, I., \& Chen, G. (2015). A System for Mining Interesting Tourist Locations and Travel Sequences From Public Geo-Tagged Photos. Data And Knowledge Engineering. Https://Doi.Org/10.1016/J.Datak.2014.11.001

Meesala, A., \& Paul, J. (2018). Service Quality, Consumer Satisfaction and Loyalty In Hospitals: Thinking For The Future. Journal of Retailing And Consumer Services. Https://Doi.Org/10.1016/J.Jretconser.2016.10.0 11

Rajesh, R. (2017). Impact of Tourist Perceptions, Destination Image and Tourist Satisfaction On Destination Loyalty: A Conceptual Model. Pasos Revista De Turismo Y Patrimonio Cultural. Https://Doi.Org/10.25145/J.Pasos.2013.11.039

Sekaran, U., \& Bougie, R. (2014). Research Methods For Business. In Research Methods For Business (P. 436).

Sheeran, P., \& Webb, T. L. (2016). The Intention-Behavior Gap. Social And Personality Psychology Compass. Https://Doi.Org/10.1111/Spc3.12265

Stathopoulou, A., \& Balabanis, G. (2016). The Effects of Loyalty Programs on Customer Satisfaction, Trust, And Loyalty Toward High- And Low-End Fashion Retailers. Journal of Business Research. Https://Doi.Org/10.1016/J.Jbusres.2016.04.177

Stylos, N., Vassiliadis, C. A., Bellou, V., \& Andronikidis, A. (2016). Destination Images, Holistic Images And Personal Normative Beliefs: Predictors Of Intention To Revisit A Destination. Tourism Management. Https://Doi.Org/10.1016/J.Tourman.2015.09.00 6

Utami, N. D., \& Ferdinand, A. T. (2019). Analisis Peningkatan Minat Berkunjung Kembali Pada Wisatawan Melalui Citra Wisata dan Nilai Budaya (Studi Pada Kota Kuningan, Jawa Barat). Jurnal Sains Pemasaran Indonesia (Indonesian Journal of Marketing Science). Https://Doi.Org/10.14710/Jspi.V17i3.207-221

Wu, C. W. (2016). Destination Loyalty Modeling of The Global Tourism. Journal of Business Research Https://Doi.Org/10.1016/J.Jbusres.2015.12.032

Xu, C., Peak, D., \& Prybutok, V. (2015). A Customer Value, Satisfaction, and Loyalty Perspective of Mobile Application Recommendations. Decision Support Systems. Https://Doi.Org/10.1016/J.Dss.2015.08.008

Zhang, H., Fu, X., Cai, L. A., \& Lu, L. (2014). Destination Image and Tourist Loyalty: A Meta-Analysis. Tourism
Management. 
Vol. 7 No 2, 2019

Https://Doi.Org/10.1016/J.Tourman.2013.06.00

6 